\title{
The Posted Workers and their difficulties in European Union
}

\author{
Antonio Dickson Sobrinho' ${ }^{1}$ Mário Vaz
}

${ }^{1}$ Faculty of Engineering, University of Porto, PT (up20171732@fe.up.pt) ORCID 0000-0003-4457-3081, 22Associated Laboratory for Energy, Transports and Aeronautics (PROA/LAETA), Faculty of Engineering, University of Porto, PT (gmavaz@fe.up.pt) ORCID 0000-0002-6347-9608 https://doi.org/10.24840/978-972-752-260-6 0056-0060

\begin{abstract}
Introduction: The present European Union (EU) society is divided into several economic classes that share the same goal and ensure their well-being through funds obtained from their work. Then, the man must perform work, independently or for his employer, and be economically compensated for it. For this reason, the man moves to regions where there is a demand for labor and preferably where it is well remunerated. We are dealing here with a special class of displaced workers, a population mostly made up of people with no greater qualifications or skills. These people need work to be able to guarantee their livelihood and that of their families. Having at work their only wealth these people seek to meet the need for EU mobility of workers becoming vulnerable to employers without respect for labor laws and Occupational Safety and Health (OSH) rules. It is important to know that a posted worker is an employee who is sent by his / her employer to work temporarily in another country to provide a cross-border service. This is not the same as a long-term mobile worker, who lives and works for an indefinite period in another Member State, or a cross-border worker, who lives in Member State A but works in Member State B. Introduction: Behind the designation of "displaced worker" there is a disregard of labor and economic legislation in many EU countries. Methodology: Systematic review in Science Direct and Web of Science databases, using Prisma P tool, and data Parliament and European Commission and EU-OSHA. Results: Research, studies, and articles point to disrespect by Unions, industry and entrepreneurs of Labor legislation, Occupational Safety and Health of Posted Workers. Conclusion: The analysis resulted in a very real picture of the condition of the worker posted in the EU. Better protection for several categories of workers were took by the European Parliament: the new rules will apply to temporary agency workers and workers in chain posting to ensure also for them the principle of equal pay for equal work at the same place. Workers in non-genuine posting will be protected too. Member States will have 2 years to implement the new rules into their national legislation. They will then have to apply and start enforcing the rules.
\end{abstract}

Keywords: Temporary Work, Work conditions, Construction Industry.

\section{INTRODUCTION}

In current EU legislation the movement of cross-border posted workers is seen as a smart and unique way of meeting the need to provide services where it is urgent in the context of freedom of movement for workers. Unfortunately the right to equal treatment has been only partially attended when comparing national citizens with citizens from other countries. The role and impact of this displacement for specific sectors as well as regions and countries are significant and are being discussed in the European Parliament (PWD-European Parliament, 2017). This work wanted to draw attention to a singular fact that is the exploitation of man by man himself or by the so-called consumer society. The main intention was to point out facts observed in the research that are of paramount importance for the safety and health of man. Workplaces of multiple employers, the result of the fragmentation of work and the outsourcing of most of the work to more specialized companies, creating a long chain of subcontracting in which there are native and foreign providers (Marchington et al., 2005). In the EU, many subcontractors post their workers from other EU countries under the Posting of Workers Directive (Directive 96/71 / European Commission (EC). This is often the case in the agriculture, meat industry, the marine industry, and the civil construction, the sector most benefiting from this action with $43.7 \%$ of the 1.92 million A1 documents issued in 2014 by the Member States declarants (Pacolet and De Wispelaere, 2015). The company filing involves only skilled workers (Pipers, Electricians, Welders, etc.). In addition, companies that receive the most displaced workers are generally large contractors, while the shipping companies are generally SMEs that provide services along the subcontracting chain (FGB and COWI, 2016; Idea Consultant Ecorys Netherlands, 2011; ISMERI Europa, 2012), showing total disregard for the conditions of the Posting of Workers Directive (Directive 96/71 / EC). 


\section{METHODOLOGY}

A systematic review with the theme "Posted Workers in U.E." was done, using quotes to restrict the objectives in the databases, Science Direct and Web of Science, using the Prisma P tool, and the Mendeley Manager. Eligibility criteria used: Time: 2015 to 2019; Document Type: Articles; Sources: Journals and Review Journals; Lingua: English and also the appropriate key words (KW). After collecting 44 articles related to its main theme, and applying the "eligibility criteria", excluding duplicities, a total of 10 articles were obtained (SD: 04 and WofS: 06). Also performed data search, together with government agencies (Parliament and the European Commission) and non-governmental organizations, EU-OSHA, to obtain official information, focusing on the posted worker, his workplace, Occupational Safety and Health (OSH) conditions and the inherent PWD legislation, which resulted in 03 documents to the theme. In addition, two more articles came from the transnational conference "Employment / Working Conditions, Occupational Safety and Health of the Posted Workers" in Ljubljana, (2017). This conference was of great importance to the EU as were discussed new and current challenges related to occupational health and safety (OSH), work and working conditions of workers. At the end of this search were obtained a total of 12 articles plus 03 documents from governmental organizations, to support this work.

\section{RESULTS}

In the current European Union, the posting of workers has become a standard way for companies to reduce wage costs. Subcontracting is a fundamental feature in the restructuring of labor relations and has brought various changes between contingent and direct employment, and between contingent forms of labor (Forde et al., 2009), unequal terms and conditions among workers employed by different contractors (Lillie, 2012), lack of clarity about where to address complaints (Fudge, 2012, Marchington et al., 2005) and between workers and the employer(s). In general, there are two main "models" of posting: one driven by labor cost differentials, the other driven by scarcity and demand for skilled and highly skilled workers. Poland, Slovenia and Portugal send the majority of the posted workers, with respectively $124,472,52,754$ and 43,823 PDs A1, while the main destinations of the posted workers are Germany, France and Belgium, respectively receiving 131,066, 54,691, 53,601 PDs A1. In particular, Slovenia, Croatia, Hungary, Poland, the Czech Republic, Estonia, Lithuania and Portugal have specialized in sending workers to work in construction and this sector absorbs over half of Belgium, Luxembourg, Liechtenstein, Austria, Slovenia, Finland, Sweden and Latvia (Pacolet and De Wispelaere, 2015: 38-39). The survey has shown gross negligence in monitoring these flows of people due to the "proper use" of the posting of workers in violation of national and European regulations. On "proper use", construction employers benefit from these workers in reducing costs in social security contributions and taxes because there is a large difference between sending and receiving countries with variations of up to $25-30 \%$ of gross value (Bernaciak, 2015, Bernsen and Lillie, 2015, Cremers, 2011, Voss et al., 2016). Temporary workers are paid the minimum amount, instead of salaries in force in the countries of destination, without local or internal collective agreements, applied to those who work in national companies. Despite the lack of statistics on the real basic salaries of the workers mentioned, research has shown that IDPs earn less (between $€ 5-€ 8 / h$ ) than local workers, particularly labor-intensive sectors such as construction, transportation, tourism, or care work (Berntsen and Lillie, 2015, Voss et al., 2016). In the Netherlands, the salaries of workers seconded to construction were sometimes below the universal minimum wage, documented trade unionists (FGB and COWI, 2016). Research by employers' organizations shows that in Denmark "posted 
workers earn on average $10 \%$ to $15 \%$ less than local workers" (FGB and COWI, 2016: 81). A comparison between established and actual minimum wages shows that in Germany "the average gross hourly wage in the construction sector-17.11 euros (Federal Bureau of Statistics) -is 32\% higher than the minimum wage for skilled workers and $56 \%$ higher than the minimum wage of unskilled workers in West Germany "(ISMERI, 2012: 43-44).

\section{DISCUSSION}

The present research showed us different views that participants have from the same segment. So far, this work force has largely fallen outside the scope of the host country's trade union representation. High labor turnover, language barriers, and limited trade union resources hamper solidary relationships between trade unions and outreach workers (Wagner and Lillie, 2014). Krings (2009), in a comparative study within the EU highlights notable differences between the UK, Austria, Germany and Ireland, of how unions engage with migrant workers. Alho (2013) supports, emphasizing trade union strategies Finnish restrictions on workers. According to Andrijasevic (2015), there are two aspects to the discussion: the view of "social dumping", which considers the migration of labor unsettling to the industrial commitments existing in Western Europe; and the "integrationist" perspective, which sees migration beneficial to the prospects of economic growth. In the industrial view, according to supporters of the first strand, they identify the causes of social dumping in west-east industrial relocation and the eastwest posting of workers (Caro et al., 2015). The difference in social patterns and wages results in a "bottom run", a downward pressure on social and living standards in the (old) EU-15. Associates of the second strand suggest that, despite popular anxieties about job displacement, the free mobility of Eastern European workers is beneficial to the EU-28 (current) (Bonin et al., 2008; Kahanec et al., 2010). The EU-15 needs a new workforce due to the aging of the population and filling jobs in a secondary market characterized by temporary contracts and lower wages. The labor migration, discovered in the case study at the Foxconn Electronics plants in the Czech Republic (Andrijasevic, 2015), is stimulated by the EU labor market perspectives and the subjective desires of migrant workers to create new and better social and economic opportunities. Construction workers who provide construction services mostly perform laborintensive tasks and therefore need to work longer hours for lower wages than the receiving countries. Their health and safety are more likely to be at risk and receive no training. In many cases, outsourcing in construction involves a multilevel subcontracting system involving posted workers who come from different countries and therefore have difficulty communicating with each other at the construction site (Cremers, 2011; Idea Consult and Ecorys Netherlands, 2011; Ouali, 2012; Thörnqvist and Bernhardsson, 2015). These outworkers have little awareness of their rights, even for lack of union representation and isolation, in recipient countries (Wagner and Lillie, 2014). Clark (2012) pointed out issues in the Civil Construction sector in the United Kingdom, which is a local industry with an internationalized labor market, a contingent labor force and the largest number of temporary workers in the country. The research questions were: What are the health problems in multinational construction workplaces where part of the workforce is posted from other EU countries? How were these issues addressed in the UK? The workforce was made up of locally hired workers and postage (20\%). The displaced were from Spain, Poland, Ireland, Slovenia and Slovakia. The projects operated under the National

Agreement for the Engineering Construction Industry (NAECI), showing that there was agreement from the local authorities. He argued that working in a transnational and multiracial environment brought the temporary worker, incompatibility of skills and inadequate assignment of tasks, pointed out as factors of direct action for the health and safety in the workplace. He 
emphasized that when performing their tasks, they expose themselves to several occupational health and safety risks. The level of exposure may be higher or lower depending on the level information and culture of this worker. Sargeant and Tucker (2009) proposed a framework of "layers of vulnerability" to identify OSH risks to migrant workers in general. They identified three sets of factors to be seen. - The first includes migration factors: migration status and the conditions of their recruitment. The second includes characteristics typical of migrant workers: socio-economic conditions in the country of origin, educational level and skills, and their language skills. - The third one identifies the conditions of the recipient country, ie characteristics of employment and the sector, access to collective representation, access to regulatory protection and particular problems of exclusion and social isolation. Industry accounts for $69.1 \%$ (including construction with $45 \%$ ), services for $29.4 \%$ and agriculture and fisheries for 1.5\% (European Commission, 2017). Over the past 20 years, the EU economy and labor market has evolved considerably, requiring a revision of legislation. Businesses take advantage of the difference in labor costs between EU countries, which can lead to unfair competition. According to the European Commission, posted workers can earn up to $50 \%$ less in some cases. By 2015, there were 2.05 million posted workers in the EU. Posting increased $41.3 \%$ between 2010 and 2015 .

\section{CONCLUSIONS}

Based on this picture, it is evident the different dimensions of migrant labor and how hard they are affected in the OHS vulnerabilities of the workers. The analysis of the articles made it possible to draw a very realistic, even cruel, picture of the circumstances that occur to the worker displaced in the EU, especially in the field of construction, where it is possible to detect mockery and disregard for all types of OSH legislation, Social and Labor, is of common use and commonplace. In summary, disrespect for decent working conditions is typical of large and small construction sites, requiring that there be an active inspection and exemplary penalty, by the authorities of the Government of the UE. The results of the study indicated as factors contrary to the safety and health of workers: Long and intense working days and hours extras were common in the workplace. Inter-linguistic communication also presented a challenge in terms of occupational health and safety issues. Better protection for several categories of workers were took by the European Parliament: the new rules will apply to temporary agency workers and workers in chain posting to ensure also for them the principle of equal pay for equal work at the same place. Workers in non-genuine posting will be protected too. In 2017, 2.8 million posting operations took place in the EU. The EU average duration for such operations is less than 4 months. Given the short duration of most postings, when converted into full-time jobs this amounts only to $0.2 \%$ of total EU employment.

\section{References}

Alho R (2013) "Varieties of capitalism and translocal linkages shaping trade union strategy in the context of transnational labor mobility". Nordic Journal of Working Life Studies 3(3): 133-153.

Altreiter, C., Fibich, T. and Flecker, J. (2015). "Capital and labour on the move: the dynamics of double transnational mobility". In: Drahokoupil, J. (ed.) The outsourcing challenge. Organizing workers across fragmented production networks. Brussels: ETUI.

Andrijasevic, R, Sacchetto D, (2016) "From labour migration to labour'mobility? The return of the multinational worker in Europe"; Vol. 22(2) 219-231; sagepub.co.uk/ journals Permissions.nav; DOI: 10.1177/1024258916635975 
Bonin H, Eichhorst W, Florman C, Hansen MO, Skio" Id L, Stuhler J, Tatsiramos K, Thomasen H and Zimmermann KF (2008) "Geographic Mobility in the European Union: Optimising Its Economic and Social Benefits". Institute for the Study of Labor, Research Report no.19.

Berntsen, L. and Lillie, (2015). "Breaking the law? Varieties of social dumping in a Pan-European labour market". In: Bernaciak, M. (ed.) Market Expansion and Social Dumping in Europe. London: Routledge, pp. 43-60.

Caro E, Berntsen L, Lillie N and Wagner I (2015) "Posted Migration and Segregation in the European Construction Sector". Journal of Ethnic and Migration Studies 41(10): 1600-1620.

Clark, N. (2012). "Regulation and Enforcement of Posted Workers Employment Rights". Country Report: UK. Working Lives Research Institute.

Cremers, J. (2010)." In search of cheap labour in Europe Working and living conditions of posted workers. Part 1 Synthesis report" (Project VS/2009/0475). Brussels: European Federation of Building and Woodworkers.

Cremers, J. (2011)." In search of cheap labour in Europe. Working and living conditions of posted workers". Brussels: European Federation of Building and Woodworkers, CLR.

Fondazione Giacomo Brodolini, COWI (2016). "Study on wage setting systems and minimum rates of pay applicable to posted workers in accordance with Directive 96/71/EC in a selected number of Member States and sectors". Luxembourg: Publications Office of the European Union.

Forde, C., MacKenzie, R., \& Robinson, A. (2009). "Built on shifting sands: Changes in employers' use of contingent labour in the UK construction sector". Journal of Industrial Relations, 51(5), pp. 653-667.

Fudge, J. (2012). "Precarious migrant status and precarious employment: The paradox of international rights for migrant workers". Comp. Lab. L. \& Pol'y J., 34, 95. . Programme and Book of Proceedings 15

Idea Consult and Ecorys Netherlands (2011). "Study on the economic and social effects associated with the phenomenon of posting of workers in the European Union". Brussels: European Commission. ec.europa.eu/social/ BlobServlet?docld=6678\&langld=en ( accessed 10 Mar 2017)

ISMERI Europa (2012). "Preparatory study for an impact assessment concerning the possible revision of the legislative framework on the posting of workers in the context of the provision of services. Final repor"t. Brussels: European Commission. ec.europa.eu/social/BlobServlet?docld=7511\&langld=en (last accessed 10 Mar 2017)

Kahanec M, Zaiceva A and Zimmermann KF (2010) Lessons from migration after EU enlargement. In: Kahanec M and Zimmermann KF (eds) EU Labor Markets After Post-Enlargement Migration.Berlin: Springer Verlag,pp. 3-46

Krings T (2009) A race to the bottom? Trade unions, EU enlargement and the free movement of labour. European Journal of Industrial Relations 15(1): 49-69.

Lillie, N. (2012). "Subcontracting, posted migrants and labour market segmentation in Finland". British Journal of Industrial Relations, 50(1), pp. 148-167.

Marchington, M. (2005).“Fragmenting work: Blurring organizational boundaries and disordering hierarchies”. Oxford University Press National Joint Council (2008) NJC "Guide to Health, Safety and Welfare". Available at http://www.njceci.org.uk/publication/download-the-njc-guide-to-health-safetywelfare-in-pdf-format-free-ofcharge/wppa_open/ (last accessed 16 June 2017)

Ouali, N. (2012). "Regulation and Enforcement of Posted Workers Employment Rights (PostER). Belgian Case Study Final Report". Brussels: ULB. Programme and Book of Proceedings. 21

Pacolet, J., De Wispelaere, F. (2015). "Posting of workers Report on A1 portable documents issued in 2014". Brussels: European Commission. ec.europa.eu/social/ BlobServlet?docld=15348\&langld=en (last accessed 10 Mar 2017)

Sargeant, M., \& Tucker, E. (2009). "Layers of vulnerability in occupational safety and health for migrant workers: case studies from Canada and the UK". Policy and practice in health and safety, 7(2), pp. 51-73

Thörnqvist, C. and Bernhardsson, S. (2015). "Their own stories - how Polish construction workers posted to Sweden experience their job situation, or resistance versus life projects". Transfer 21(1): pp. 23-36.

Voss, E., Faioli, M., Lhernould, J.P., ludicone, F. (2016). "Posting of Workers Directive - current situation and challenges". Brussels: European Parliament.

Wagner, I. and Lillie, N. (2014). "European Integration and the Disembedding of Labour Market Regulation: Transnational Labour Relations at the European Central Bank Construction Site". Journal of Common Market Studies 52(2): pp. 403-419. 